Alicja JAWOR

Antoni SKOWROŃSKI

IEiB UKSW Warszawa

\title{
Realizacja Naprawczego Programu Ochrony Powietrza w strefie "aglomeracja warszawska"
}

\begin{abstract}
Wstęp
Jesteśmy coraz częściej świadkami różnych anomalii pogodowych i meteorologicznych. Niepokojące wieści o tym, płyną do nas z całego świata: niespotykane dotąd huragany powodzie czy susze. W dużej mierze jest to bezpośredni i dostrzegalny efekt postępujących zmian klimatycznych. Konsekwencją tych anomalii są nie tylko problemy o charakterze ekologicznym lecz również gospodarczym i społecznym. Dla przykładu, stacja telewizyjna CNN podała, że postępujące ocieplenie atmosfery może prowadzić do wzrostu poziomu wód w morzach i oceanach o pół metra do 2050 roku, a to z kolei może narazić na straty w wysokości 28 bilionów dolarów największe miasta leżące na wybrzeżach. Takie wnioski przedstawia raport opracowany przez branżę ubezpieczeniową ${ }^{1}$. Tak niepokojące perspektywy skłaniają do poszukiwań nowych rozwiązań w zakresie ochrony atmosfery. Jednym $\mathrm{z}$ mechanizmów już stosowanych, jest zarządzanie jakością powietrza.

Niniejszy artykuł przede wszystkim skupia się na inicjatywach i działaniach podejmowanych na obszarze aglomeracji warszawskiej, a służących zminimalizowaniu zanieczyszczeń wprowadzanych do powietrza. Jest to główny cel realizacji Naprawczego Programu Ochrony Powietrza (NPOP), aby doprowadzić do przywrócenia dopuszczalnych wartości stężeń $\mathrm{PM} 10$ i NO 2 zgodnych z przyjętymi normami wynikającymi z faktu członkowstwa Polski w Unii Europejskiej. Oprócz tego, w artykule zostaną przedstawione ogólne informacje nt. zanieczyszczeń powietrza i informacje charakteryzujące analizowany obszar badawczy, czyli aglomerację warszawską.
\end{abstract}

\footnotetext{
1 Informacja za: http://biznes.onet.pl, z dnia 23.11.2009 r.
} 


\section{Zanieczyszczenie powietrza}

Możemy spotkać się z różnymi definicjami i określeniami tłumaczącymi pojęcie „zanieczyszczenie powietrza”. Są to „wszystkie substancje stałe, ciekłe, gazowe, których udziały w powietrzu przekraczają swoją średnią wartość tych substancji w czystym powietrzu atmosferycznym”2. Inna definicja mówi, że są to substancje, które wywierają negatywny wpływ na każdą istotę żywą czy to roślinę, zwierzę czy człowieka, a uwolnienie ich do atmosfery powoduje odchylenie składu powietrza od jego stanu średniego ${ }^{3}$. Prawo ochrony środowiska określa zanieczyszczenie jako „...emisję, która może być szkodliwa dla zdrowia ludzi lub stanu środowiska, może powodować szkodę w dobrach materialnych, może pogarszać walory estetyczne środowiska lub może kolidować $\mathrm{z}$ innymi, uzasadnionymi sposobami korzystania ze środowiska" ${ }^{4}$. Według Światowej Organizacji Zdrowia [WHO], o zanieczyszczeniu można mówić zawsze, kiedy „znajdujące się w nim pierwiastki lub inne substancje szkodliwe dla zdrowia ludzi i zwierząt, powodują uszkodzenia roślin, przyczyniają się do powstawania innych szkód lub wywierają ujemny wpływ na środowisko".

Tak rozumiane zanieczyszczenia zmieniają ilościowo i jakościowo powietrze, poprzez stężenie w nim różnych substancji składowych. Wyróżniamy stężenie masowe i objętościowe. Stężenie masowe $\left(\mathrm{S}_{\mathrm{m}}\right)$ jest równe stosunkowi masy zanieczyszczenia czy to pyłowego czy gazowego $\left(\mathrm{m}_{\mathrm{z}}\right)$ do objętości tzw. ośrodka dyspersyjnego tj. powietrza $\left(\mathrm{V}_{\mathrm{g}}\right)$ jako miejsca rozprzestrzeniania się zanieczyszczenia. Stężenie takie wyraża się $\mathrm{w} \mathrm{g} / \mathrm{m}^{3}, \mathrm{mg} / \mathrm{m}^{3}$ czy też $\mu \mathrm{g} / \mathrm{m}^{3}$.

$$
\mathrm{S}_{\mathrm{m}}=\mathrm{m}_{\mathrm{z}} / \mathrm{V}_{\mathrm{g}}
$$

Stężenie objętościowe $\left(\mathrm{S}_{\mathrm{v}}\right)$ to stosunek objętości zanieczyszczenia gazowego $\left(\mathrm{V}_{\mathrm{z}}\right)$ do objętości ośrodka dyspersyjnego $\left(\mathrm{V}_{\mathrm{g}}\right)$

$$
\mathrm{S}_{\mathrm{v}}=\mathrm{V}_{\mathrm{z}} / \mathrm{V}_{\mathrm{g}}
$$

Jednostki stosowane w problematyce to wartości bezwzględne, $\mathrm{np} . \mathrm{w} \mathrm{cm}^{3} / \mathrm{m}^{3}$ lub względne, tj. procenty [\%].

Koncentrację zanieczyszczeń odnosi się zazwyczaj do objętości gazu przeliczonego na umowne warunki, jakimi są: temperatura $\mathrm{T}=273,15 \mathrm{~K}\left(\mathrm{t}=\mathrm{O}{ }^{\circ} \mathrm{C}\right)$,

2 Z. BAGIEŃski, System ochrony powietrza. Zagadnienia wybrane, Wyd. Fundacja na rzecz rozwoju Politechniki Poznańskiej, Poznań 2003, s.17.

3 Por. M. Markiewicz, Podstawy modelowania rozprzestrzeniania się zanieczyszczeń w powietrzu atmosferycznym, Wyd. Oficyna wydawnicza Politechniki Warszawskiej, Warszawa 2004, s. 31; R. OlaczeK, Słownik Szkolny..., dz. cyt. ,s. 284; J. GreszKa, A.Gruszka, M. KowalkowsKa, Wplyw imisji na ekosystem, Wyd. „Śląsk” Wydawnictwo Naukowe, Katowice 2002, s. 25; K. JudAReZler, Oddziaływanie zanieczyszczeń powietrza na środowisko, Wyd. Oficyna wydawnicza Politechniki Warszawskiej, Warszawa 2000, s. 11, 17-18.

4 Art. 3 ustawy z dnia 27 kwietnia 2001 r. Prawo ochrony środowiska (Dz. U. 2001, nr 62 poz.627). 
ciśnienie, p=760 mm Hg, czyli 1013,25 kPa ${ }^{5}$. Mówiąc o zanieczyszczeniu powietrza koniecznym jest wyjaśnienie kolejnych terminów: emisji i imisji wraz z odpowiadającymi im jednostkami.

Przez emisje należy rozumieć wprowadzanie do środowiska substancji bądź energii. Jest to strumień zanieczyszczający, wprowadzany do atmosfery z emitora, jakim może być komin, wyrzutnia wentylatorowa czy rura spalinowa ${ }^{6}$. Wskaźniki emisji mogą odnosić się do jednostki surowca, np. gSO $/ 2$ kg paliwa jak też i do jednostki produktu gSO $/$ /GJex (energii wyprodukowanej). Natomiast „imisję" rozumie się ładunek emisji, czyli powstałe stężenie na skutek emisji i dyspersji zanieczyszczenia. Imisja bezpośrednio oddziałuje na świat organiczny i inne receptory. Wartości stężeń imisyjnych oblicza się, szacuje, bądź wyznacza za pomocą matematycznych modeli dla konkretnych zanieczyszczeń, czasu oraz obszaru ich występowania. Jednostka stosowana w odniesieniu do ww. pojęcia to $\mu \mathrm{g} / \mathrm{m}^{37}$.

Najogólniej ujmując, zanieczyszczenia do atmosfery są emitowane ze źródeł naturalnych i sztucznych (antropogenicznych). Naturalna emisja to taka, której źródła związane są z funkcjonowaniem przyrody. Zliczamy do niej wybuchy wulkanów, huragany, pożary lasów łąk, czy procesy biologiczne zachodzące w przyrodzie ${ }^{8}$. Antropogeniczne źródła pochodzą głównie z urządzeń i związanych z nimi procesów technologicznych, podczas których wydzielane są pyły, gazy, aerozole czy odory jako produkty uboczne. Tu można podzielić źródła na stacjonarne (nieruchome) i mobilne lub biorąc pod uwagę typy emitorów: punktowe, liniowe i powierzchniowe. Opierając się o systematykę przyjętą przez system CORINAIR ${ }^{9}$, wyodrębnia się najważniejsze kategorie źródeł:

- procesy spalania w produkcji energii;

- procesy spalania w przemyśle;

- procesy spalania paliw w ciepłowniach i w kotłowniach;

- procesy produkcyjne;

- transport drogowy i inny;

- zagospodarowanie i unieszkodliwianie odpadów;

- gospodarka rolna.

5 Por. Z. Bagieński, System ochrony..., dz. cyt., s. 18-19; M. Markiewicz, Podstawy modelowania..., dz. cyt. s. 32.

6 Por. J. JęDrośka, M. Bar, Prawo ochrony środowiska. Podręcznik, Wyd. Centrum Prawa Ekologicznego, Wrocław 2005, s. 36.

Por. Z. BAgIeŃski, System ochrony..., dz. cyt., s. 23.

8 Zob. tamże, s. 12-13; M. Markiewicz, Podstawy modelowania..., dz. cyt. s. 33, M. SzKLARCzyK, Ochrona atmosfery, Wyd. Uniwersytetu W-M, Olsztyn 2001, s. 22, 24; J. JęDrośKA, M. BAR, Prawo ochrony..., dz. cyt., s. 273; A. JAGUsIEwICz, Powietrze-człowiek-środowisko, Wyd. Ludowa Spółdzielnia Wydawnicza, Warszawa 1981, s. 28-31.

9 Klasyfikacja - CORINAIR Coordination Information Enviromental Air Emisions Inventory, system informacji na temat inwentaryzacji emisji, nadzorowany przez Europejską Agencję Środowiska (EEA); zob. Z. BAgIEŃski, System ochrony..., dz. cyt., s. 25. 
W chwili obecnej największą odpowiedzialność za stan zanieczyszczenia atmosfery ponosi człowiek. Na nas też spoczywa ochrona tego wyjątkowego zasobu. Jednym ze sposobów jest system zarządzania jakością powietrza obejmujący m.in. instrumenty prawne i administracyjne, które wymuszają stosowanie odpowiednich metod planistycznych, technologicznych, rozwiązań inżynieryjnych $\mathrm{i}$ inwestycyjnych.

\section{Naprawczy Program Ochrony Powietrza (NPOP)}

Zarządzanie jakością powietrza poprzez utworzenie i funkcjonowanie Naprawczego Programu Ochrony Powietrza (NPOP), jest wynikiem implementacji do prawa polskiego art. 8 ramowej dyrektywy Rady Europejskiej 96/62WE w sprawie oceny i zarządzania jakością otaczającego powietrza ${ }^{10}$. NPOP jest niezwykle innowacyjnym instrumentem prawnym, stanowiącym zasadniczą metodę służącą przeciwdziałaniu zanieczyszczeniom atmosfery, a ponad to instrumentem wzmacniającym pozycję prowadzonej polityki ekologicznej Polski w skali międzynarodowej.

Wstępnym, a zarazem podstawowym celem tego programu jest inwentaryzacja emisji zanieczyszczeń powietrza. Pozwala to na klasyfikację stref w danym województwie pod kątem przekraczania przez poszczególne substancje poziomów dopuszczalnych lub docelowych (oraz przekroczenie poziomu dopuszczalnego lub docelowego powiększonego o margines tolerancji, jeżeli został on określony dla danego zanieczyszczenia i czasu uśredniania). Ponadto bezwzględny obowiązek wykonywania NPOP dotyczy zarówno substancji, dla których w wyniku oceny rocznej stwierdzono przekroczenie poziomów dopuszczalnych jak i przekroczenie poziomów docelowych (w tym przypadku możliwe jest jednak niepodejmowanie określonych działań naprawczych, jeżeli nie są one ekonomicznie uzasadnione, musi być spełniony warunek polegający na przeanalizowaniu tych substancji wraz z odpowiednim ich udokumentowaniem). W ocenie uwzględniane są wszystkie zanieczyszczenia wymienione w rozporządzeniu Ministra Środowiska w sprawie dopuszczalnych poziomów niektórych substancji w powietrzu, alarmowych poziomów niektórych substancji w powietrzu oraz marginesów tolerancji dla dopuszczalnych poziomów niektórych substancji ${ }^{11}$.

W oparciu o przedstawione zasady, ocena jakości powietrza za rok 2004 oraz lata 2005-2006, dokonana w ramach Państwowego Monitoringu Środowiska

10 Dyrektywa Rady 96/62/WE w sprawie oceny i zarządzania..., dz. cyt. (Dz. Urz. WE L296 z 21.11.1996 r).

11 Rozporządzenie Ministra Środowiska z dnia 6 czerwca 2002r.w sprawie dopuszczalnych poziomów niektórych substancji w powietrzu, alarmowych poziomów niektórych substancji w powietrzu oraz marginesów tolerancji dla dopuszczalnych poziomów niektórych substancji (Dz.U. Nr 87, poz. 796). 
przez Wojewódzki Inspektorat Ochrony Środowiska w strefie aglomeracja warszawska, wykazała ponadnormatywne wartości pyłu zawieszonego PM10 oraz $\mathrm{NO}_{2}$ w powietrzu atmosferycznym, co uniemożliwia utrzymanie dopuszczalnych norm substancji zanieczyszczających na obszarze miasta ${ }^{12}$. W związku z tym Wojewoda Mazowiecki zgodnie z art. 91 ust. 3 ustawy POŚ zobowiązany został do określenia Programu, zadaniem którego było przywrócenie dopuszczalnych norm tychże związków ${ }^{13}$. Rozporządzeniem nr 67 z dnia 24 grudnia 2007 roku organ ten określił Program Ochrony Powietrza dla strefy aglomeracja warszawska, które opublikowane zostało w Dzienniku Urzędowym Województwa Mazowieckiego Nr 269 z dnia 31 grudnia 2007 roku, poz. $9320^{14}$.

Program ten jest instrumentem prawnym, stosowanym w celu obniżenia imisji zanieczyszczeń i stanowi tym samym zasadniczą metodę służącą przeciwdziałaniu oraz minimalizowaniu szkód powodowanych zanieczyszczeniem atmosfery w Warszawie i jej najbliższej okolicy.

\section{Ponadnormatywne poziomy emisji zanieczyszczeń powietrza wynikiem niezrównoważonej urbanizacji aglomeracji warszawskiej}

Nie istnieją jasno określone granice aglomeracji warszawskiej. Umownie przyjmuje się, że jest to silnie zurbanizowany obszar w skład którego wchodzi Warszawa oraz liczne miasta i wsie województwa mazowieckiego położone do 40-50 km od stolicy. Centrum aglomeracji stanowi Warszawa. Jest ona głównym ośrodkiem polityczno-kulturowym Polski. Obszar miasta przecina środkowy bieg Wisły, który dzieli je na część prawo i lewobrzeżną. Miasto stanowi gminę o powierzchni $517 \mathrm{~km} \mathrm{kw}^{2}$, w której poszczególne części mają status dzielnic, posiadając tym samym ograniczone kompetencje samorządowe. Granice Warszawy poszerzyły się o gminę Wesoła, tworząc w sumie 18 dzielnic. Według danych Urzędu Statystycznego w Warszawie liczba ludności osiągnęła 1706600 mieszkańców. Gęstość zaludnienia wynosi 3301 osób/ km². Organem wykonawczym miasta jest Prezydent m.st. Warszawy. Organem kontrolnym i stanowiącym Rada

12 K. Barańska, M. Gąsior, E. Tręinińska, Druga pięcioletnia ocena jakości powietrza w województwie mazowieckim za lata 2002-2006, Wyd. Wojewódzki Inspektorat Ochrony Środowiska w Warszawie, Warszawa 2007, s. 9-12, 20-21.

13 Inf. A. Buczyński, Zielone Mazowsze, Zob. Zielone Mazowsze, Wg kategorii, Dokumenty, Warszawa, Raporty, Wojewoda Mazowiecki - Zgłoszone uwagi do programu powietrza Warszawy, [w:] http://www.zm.org.pl/?a=pop_warszawa-082 (27.02.2009 r.).

14 Mazowiecki Urząd Wojewódzki w Warszawie, Szukaj, Program Ochrony Powietrza, [w:] http:// www.mazowsze.uw.gov.pl/search.php?ns[digpdf] $=\mathrm{n} \& \mathrm{~ns}[$ digimg] $=\mathrm{n} \& \mathrm{~ns}[$ diglnk] $=\mathrm{n} \& \mathrm{~ns}[\mathrm{keywr}$ $\mathrm{d}]=$ program + ochrony + powietrza\&x=0 \&y=0 (27.02.2009); Urząd Marszałkowski Województwa Mazowieckiego, Programy, Programy Ochrony Powietrza, Program Ochrony Powietrza dla strefy Aglomeracja Warszawska, [w:] http://www.mazovia.pl/?a=news\&id=4792 (27.02.2009). 
m.st. Warszawy ${ }^{15}$. Funkcje wynikające $\mathrm{z}$ charakteru stołecznego miasta określa ustawa o ustroju miasta stołecznego Warszawy ${ }^{16}$.

Aglomerację cechuje najwyższy poziom zamożności, a zarazem najniższy poziom bezrobocia w skali kraju. We współczesnej gospodarce istotnym źródłem dochodów staje się turystyka. Stolica odgrywa ważną rolę jako główny ośrodek turystyki zagranicznej. Związane jest to bez wątpienia z lokalizacją lotniska oraz węzła będącego dobrym punktem przesiadkowym. Negatywną stroną miasta jest niezadowalający poziom bezpieczeństwa publicznego powiązany z wysokim stopniem zagrożenia przestępczością ${ }^{17}$. Atutami miasta jest m.in. duży potencjał demograficzny, silna i dynamicznie rozwijająca się metropolia, nowoczesne branże produkcji czy zasoby środowiskowe umożliwiające wdrożenie zrównoważonego rozwoju.

Wysoki poziom urbanizacji stwarza jednak zagrożenie dla walorów przyrodniczych miasta, ponadto oddziałuje on szkodliwie nie tylko na swój własny stan środowiska przyrodniczego, ale i na pozostałe sąsiadujące obszary. Korytarze transportowe, mimo iż posiadają cenne znaczenie w aktywności gospodarczej zarówno skali krajowej jak i europejskiej, charakteryzują się niską infrastrukturą techniczną, która znajduje swe konsekwencje w słabej wydajności układu komunikacyjnego. Czynniki te przyczyniają się zarówno do degradacji terenów leśnych i cennych przyrodniczo jak i postępującego zanieczyszczenia powietrza.

Działalności o której mowa wyżej towarzyszy ogromna ilość emitowanych substancji toksycznych z jednoczesnym brakiem troski o ich eliminację, spalany węgiel pozbawiony jest wcześniejszego oczyszczenia. W dalszym ciągu wysoce energochłonny pozostaje przemys ${ }^{18}$. Wśród zasadniczych przyczyn wysokich poziomów stężeń zarówno PM10 jak i $\mathrm{NO}_{2}$ wymienia się głównie:

- nadmierne natężenie ruchu pojazdów w centrum miasta;

- wysoki udział indywidualnego ogrzewania węglowego w zaspokajaniu potrzeb mieszkańców;

15 Biuletyn Informacji Publicznej m. st. Warszawy, Menu podmiotowe, Miasto stołeczne Warszawa, Informacje Podstawowe; [w:] http://bip.warszawa.pl/Menu_podmiotowe/Warszawa/ default.htm, (20.10.2008).

16 Ustawa z dnia 15 marca 2002r. o ustroju m.st. Warszawy (Dz. U. Nr 41, poz.361 ze zm.).

17 Por. Z. Bukowski, T. JęDRzejski, P. RĄCzkA, Ustrój samorządu terytorialnego, Wyd. II, Wyd. Towarzystwo Naukowe Organizacji i Kierownictwa. Stowarzyszenie Wyższej Użyteczności „DOM ORGANIZATORA”, Toruń 2005, s. 347-352; M. Cнмаj (red. ), Ustrój samorządu terytorialnego w Polsce, Wyd. Oficyna Wydawnicza Wyższej Szkoły Handlu i Prawa im. Ryszarda Łazarskiego, Warszawa 2007, s. 269-283; L. Olchownik-Adamowska, T.Ławiecki, Warszawa, Wyd. Hachette Livre Polska, sp. z. o.o, Warszawa 2005, s. 5, 6,16, 20, 30,44; K. Szczypka/K.Duran (red.), Warszawa. National geographic, Wyd. G+JRBA, Warszwa 2006, s. 3, 5, 9, 11, 13, Strategia Rozwoju Województwa Mazowieckiego do roku 2020 (aktualizacja), Samorząd Województwa Mazowieckiego pod kierunkiem prof. dr hab. Zbigniewa Strzeleckiego, Warszawa 2006, s. 8-13.

18 P. ŻUkowski Degradacja i ochrona atmosfery..., dz. cyt. s. 30. 
- wykorzystywanie wyeksploatowanych instalacji;

- lokalizacja obiektów przemysłowych w centrum miasta;

- niski poziom wiedzy ekologicznej;

- niedostateczny poziom wydatków budżetowych na ograniczanie emisji ${ }^{19}$.

$\mathrm{Z}$ danych wynika, że w samej Warszawie jest zlokalizowanych 1510 emitorów punktowych, 55739 emitorów powierzchniowych i 6535 emitorów liniowych ${ }^{20}$. Biorąc pod uwagę PM10 na ponadnormatywne wartości największy wpływ ma emisja liniowa $(67,0 \%)$ związana głównie z pyłem (kurzem) unoszonym podczas ruchu pojazdów, emisja z rury wydechowej i tarcia jest znacznie mniejsza. Śródmieście należy do obszarów najsilniej zdominowanych emisją liniową PM10. Duży procent przypada na emisję powierzchniową (20,7\%) z ogrzewania węglem i innymi paliwami stałymi ${ }^{21}$. Największe problemy wiążące się z ogrzewaniem indywidualnym, występują głównie w dzielnicy Ursus, fragmentarycznie na Pradze Północ, Południe i Targówku. Dobra sytuacja związana z ogrzewaniem zorganizowanym (gaz, elektryczność) przedstawia się głównie w Śródmieściu oraz na Mokotowie i Ursynowie. Najmniejszy udział przypada na emisję punktową (12,3\%), plusem w tym przypadku są niewielkie parametry kominów uwalniające tym samym mniejszą ilość substancji zanieczyszczających. Największa emisja spowodowana jest przez elektrociepłownię ENERGETYKA URSUS Sp. z o.o. W zawiązku z tym maksymalne zanieczyszczenie występuje głównie w północnej części miasta, na granicy dzielnic Praga Północ, Białołęka, Targówek.

Za pomocą modelowania matematycznego można przedstawić rozkład stężeń substancji emitowanych z poszczególnych źródeł. Emisja liniowa w okresie 24 godzin na większej części miasta zawiera się w przedziale $27-54 \%$ poziomu dopuszczalnego powiększonego o margines tolerancji. Przekroczenia znajdują się jak wspomniałam jedynie na obszarze Śródmieścia. Wartości stężeń o okresie uśredniania wyników pomiarów na rok kalendarzowy zawierają się pomiędzy 10-38\% poziomu dopuszczalnego powiększonego o margines tolerancji. Emisja powierzchniowa o okresie uśredniania 24 godziny zawiera się pomiędzy $25-54 \%$, biorąc pod uwagę rok kalendarzowy jest to przedział 7-14\% poziomu dopuszczalnego powiększonego o margines tolerancji. W oby dwu przypadkach przekroczenia występują w dzielnicy Ursus. Na emisję punktową maksymalne stężenia w przeciągu okresu uśredniania wyników na 24 godziny osiągają 23,6\% poziomu dopuszczalnego, w przeciągu roku zaś $20 \%{ }^{22}$.

19 Rozporządzenie Nr 67 Wojewody Mazowieckiego (Dz. U. Województwa Mazowieckiego r 269, poz 9320)..., dz. cyt., załącznik nr 3, s. 38-39.

20 Por. tamże.

21 Rozporządzenie Nr 67 Wojewody Mazowieckiego (Dz. U. Województwa Mazowieckiego Nr 269, poz. 9320), dz. cyt., załącznik nr 3, s. 26.

22 Por. tamże. 
Alicja Jawor, Antoni Skowroński

Tabela nr 1. Sumy oraz gęstości emisji PM10 i NO2 dla różnych typów źródeł zlokalizowanych na terenie aglomeracji warszawskiej w roku 2004

\begin{tabular}{|l|c|c|c|c|c|}
\hline \multicolumn{1}{|c|}{ TYP EMISJI } & $\begin{array}{c}\text { Pyi } \\
\text { zawieszony } \\
\text { PM10 } \\
{[\mathbf{M g} / \mathbf{r o k}]}\end{array}$ & $\begin{array}{c}\text { Pyl zawieszony } \\
\text { PM10 } \\
{\left[\mathbf{M g} / \mathbf{r o k} / \mathbf{k m}^{2}\right]}\end{array}$ & $\begin{array}{c}\text { Dwutlenek } \\
\text { azotu } \\
{[\mathbf{M g} / \mathbf{r o k}]}\end{array}$ & $\begin{array}{c}\text { Dwutlenek } \\
\text { azotu } \\
{\left[\mathbf{M g} / \mathbf{r o k}_{\mathbf{k}} \mathbf{k m}^{2}\right]}\end{array}$ & $\begin{array}{c}\text { Liczba } \\
\text { emitorów }\end{array}$ \\
\hline Powierzchniowa & 1513,096 & 2,92 & 506,671 & 0,98 & 4473 \\
\hline Punktowa & 901,146 & 1,74 & 11827,771 & 22,83 & 1510 \\
\hline Liniowa & 4911,551 & 9,48 & 8232,052 & 15,90 & 6535 \\
\hline w tym spaliny & 399,238 & 0,77 & - & - & - \\
\hline w tym tarcie & 227,572 & 0,44 & - & - & - \\
\hline w tym kurz & 4284,721 & 8,27 & - & - & - \\
\hline SUMA & $\mathbf{7 3 2 3 , 2 2}$ & $\mathbf{1 4 , 1 4}$ & $\mathbf{2 0 ~ 5 5 9 , 1 8 7}$ & $\mathbf{3 9 , 7 0}$ & $\mathbf{1 2 5 1 8}$ \\
\hline
\end{tabular}

Źródło: Rozporządzenie Nr 67 Wojewody Mazowieckiego (Dz. U. Województwa Mazowieckiego Nr 269, poz. 9320), dz. cyt., załącznik nr 3.

Niewłaściwy stan powietrza spowodowany działalnością innowacji przemysłowych i technologicznych, może ulec zmniejszeniu poprzez wprowadzenie odpowiednich koncepcji przeciwdziałających lub ograniczających ilość emitowanych substancji. W ramach omawianego NPOP dla aglomeracji warszawskiej, znalazła się lista propozycji, mających na celu zmniejszenie emisji PM10 i NO${ }_{2}$, tym samym zaś poprawę jakości powietrza. Działania te omówione zostaną poniżej.

\section{NPOP jako działanie zmierzające do poprawy jakości powietrza na obszarze stolicy}

Zakres działań i kierunków naprawczych objętych programem odnosi się do inwestycji związanych z trzema obszarami źródeł emisji: liniowymi (komunikacyjnymi), powierzchniowymi (komunlano-bytowymi) oraz punktowymi (energetycznego spalania paliw). Inwestycje w tychże obszarach uznano za konieczne w ramach przywrócenia dopuszczalnych poziomów emisji na obszarze miasta.

Z uwagi na fakt, iż do ponadnormatywnych wartości stężeń zanieczyszczeń w przewadze przyczynia się emisja liniowa, w tym właśnie sektorze zdecydowano się na podjęcie najszerszego zakresu zmian. W celu poprawy funkcjonowania transportu publicznego dąży się do utworzenia „Zintegrowanego Systemu Zarządzania Ruchem"23. Zasadniczym celem projektu jest polepszenie mobilności i warunków podróżowania bez jednoczesnego pogarszania warunków ruchu samochodowego w korytarzach transportowych. Efektem realizacji będzie szybsze, sprawniejsze i mniej kosztowne przemieszczanie przy spełnieniu wymogów ograniczonego, ne-

23 Tamże. 
gatywnego wpływu transportu publicznego na środowisko. Sedno wspomnianego systemu stanowi monitoring ${ }^{24}$, który stwarza możliwość zarządzania ruchem ulicznym. Dzięki oprogramowaniu możliwe staje się bowiem prognozowanie, wprowadzanie zmian w parametrach sterowania ruchem jak również zarządzanie priorytetami dla pojazdów komunikacji zbiorowej. Monitoring umożliwia również szybkie wykrywanie wypadków i incydentów wymagających interwencji oraz ostrzeganie i informowanie kierowców (radio RDS/TMC, internet i in.). W zakresie zwiększenia płynności ruchu ulicznego oraz ograniczenia „korków ulicznych”, w latach 2006-2008 system ten został zrealizowany na obszarze pierwszym tj. Powiślu, Wisłostradzie (od mostu Grota-Roweckiego) do Trasy Siekierkowskiej oraz na Alejach Jerozolimskich na odcinku od Ronda Waszyngtona do Placu Zawiszy. Pomysł bez wątpienia jest dobry, natomiast zyskałaby wiele w sytuacji zobowiązania władz Warszawy do podjęcia dodatkowych działań koordynujących inwestycje transportowe $\mathrm{z}$ gminami i powiatami sąsiadującymi ze stolicą. $\mathrm{Z}$ uwagi na fakt, iż ponad $80 \%$ ruchu samochodowego na granicy miasta kieruje się do jego centrum, należy opracować projekt zapewniający dojeżdżającym dostęp do szybkiej i sprawnej komunikacji szynowej ${ }^{25}$.

Kolejnym pomysłem wpływającym na ograniczenie emisji liniowej jest zarządzenie byłego prezydenta m.st. Warszawy Kazimierza Marcinkiewicza nr 380/2007²6, dotyczące zakazu poruszania się pojazdów o dopuszczalnej masie całkowitej powyżej 16 ton w godzinach 7:00 - 10:00 oraz 16:00 - 20:0027. Działanie to bez wątpienia przyczyni się do poprawy stanu bezpieczeństwa na drogach, mniejsze zużycie nawierzchni, uprzywilejowanie ruchu komunikacji zbiorowej i indywidualnej a tym samym poprawę stanu jakości powietrza na terenie stolicy. Dodatkowe ustalenia dotyczą zakazu poruszania się samochodów na obszarach z przewagą funkcji mieszkaniowych (do 10 t) czy też strefy zakazu ruchu pojazdów w obszarach zabytkowych (obszar Starego i Nowego miasta oraz część Mariensztatu). Rozważeniu warto poddać rozwiązanie praktykowane w Rzymie, tj. wprowadzenie stref ograniczonego dostępu w zależności od jakości spalanego paliwa, nie tonażu ${ }^{28}$.

24 A. Bartosik, Urząd miasta m.st. Warszawy, Informator dla firm, Informator dla przedsiębiorców, Zintegrowany System Zarządzania Ruchem [w:] http://www.warszawa-biznes. $\mathrm{pl} / \mathrm{pl} / \mathrm{inf} /$ ?dz=3\&me $=14 \& \mathrm{te}=898$.

25 W. Szymański, Zielone Mazowsze, Raporty, Program Ochrony Powietrza dla Warszawy [w:] http://www.zm.org.pl/?a=powietrze-078\#Uwagi_i_wnioski_Zielonego_Mazowsza, (17.04.2009).

26 Zarządzenie Prezydenta m. st. Warszawy nr 380/2007 z dnia 1 listopada 2007r. w Biuletyn Informacji Publicznej m. st. Warszawy [w:] http://bip.warszawa.pl/Menu_przedmiotowe/ zarzadzenia_uchwaly/Zarzadzenia/Prezydent_m__st__Warszawy/2007/4/25/ 33410ZarzadzeniaIUchwaly.htm, (21.04.2009).

27 Zarząd dróg miejskich, Ograniczenia ruchu samochodów ciężarowych, [w:] http://www.zdm. waw.pl/informacje/mapa-ograniczenia-tonazowego.html, (18.03.2009).

28 W. Szymański, Zielone Mazowsze, Raporty, Program Ochrony Powietrza dla Warszawy [w:] http://www.zm.org.pl/?a=powietrze-078\#Uwagi_i_wnioski_Zielonego_Mazowsza, (17.04.2009). 
Warte realizacji jest ponadto wprowadzenie nakazu tworzenia stref uspokojenia ruchu (tempo $30 \mathrm{~km} / \mathrm{h}$ ), w ramach czego sygnalizację świetlną zastąpiłby wyniesione tarcze skrzyżowań, małe ronda, esowanie toru jazdy samochodów. Elementy takie powinny znaleźć się w byłej dzielnicy Centrum oraz ulicach klasy $\mathrm{Z}$ (zbiorczych). Wspomniane strefy dodatkowo promują komunikację rowerową $\mathrm{z}$ uwagi na przyjazne warunki panujące na drogach.

W ramach realizacji polityki transportowej ustala się zasady funkcjonowania strefy płatnego parkowania niestrzeżonego. Głównym celem jest uporządkowanie systemu parkowania głównie w obszarach silnie zurbanizowanych. Działanie to przyczyni się do zachowania równowagi pomiędzy dostępnością i przepustowością układu drogowego, a chłonnością parkingową jak również uzyskanie oszczędności w przestrzeni ulic z możliwością wykorzystania jej na potrzeby transportu publicznego czy rowerowego.

Sprawny transport w mieście wymaga właściwej struktury systemu drogowego, której podstawą jest rozwinięcie układu dróg wyższych klas, tj. dróg ekspresowych (S) oraz dróg głównych ruchu przyspieszonego (GP), umożliwi to bowiem oddzielenie ruchu lokalnego od tranzytowego a ruchu osobowego od towarowego. Dlatego też kluczowe znaczenie w ramach realizacji NPOP ma budowa systemu obwodnic oraz nowych tras mostowych przez Wisłę realizowanych obecnie przez Generalną Dyrekcję Dróg Krajowych i Autostrad. Znaczna część przejazdów, a także przejazdy tranzytowe odbywa się obecnie przez Śródmieście, a nawet ścisłe centrum miasta. Sytuację tę zmieni wybudowanie obwodnic śródmiejskiej i miejskiej, które współpracować będą z obwodnicą ekspresową zapewniającą zewnętrzne powiązania Warszawy z innymi ośrodkami miejskimi ${ }^{29}$. Termin realizacji tychże inwestycji przewiduje się na rok 2015, znając jednak faktyczne przełożenie planów w praktykę, sukcesem będzie rok 2020.

Zwiększeniu ulegnie także, o czym wspomniano liczba przepraw mostowych i tras drogowych przebiegających przez Wisłę. Inwestycje te ograniczą natężenie ruchu, tym samym przyczyniając się do obniżenia poziomu emisji zanieczyszczeń. Z uwagi na fakt, iż obecnie główną arterią komunikacyjną łączącą osiedla północnej Warszawy położone po obu stronach Wisły jest most Grota - Roweckiego, w celu odciążenia ruchu realizacji poddano budowę Trasy Mostu Północnego (w nocy z 28 na 29 stycznia 2010 odbył się montaż pierwszych stalowych elementów wiaduktu Trasy Mostu Północnego (TMP) nad ul. Marymoncką, czyli obiektu WD4). Brak innej przeprawy mostowej pomiędzy Białołęką a Bielanami powoduje, że dotychczasowy ruch koncentruje się na mo-

\footnotetext{
29 Prezydent m.st. Warszawy, Informacja w zakresie ograniczenia emisji zanieczyszczeń powietrza ze źródeł komunikacyjnych. Pismo z dnia 14.08.2008 r. skierowane do Marszałka Województwa Mazowieckiego, Pana A. Struzika, informacja znajduje się w Urzędzie Marszałkowskim; por. Zarząd Dróg Miejskich Warszawa, Zintegrowany System Zarządzania Ruchem, http://www. zdm.waw.pl/zintegrowany-system-zarzadzania-ruchem.html, (21.04.2009).
} 
ście Grota-Roweckiego (146 tys. pojazdów na dobę wg danych 2003 r.) ${ }^{30}$, który jest obecnie najbardziej obciążonym mostem w mieście. Komunikacja tramwajowa poprowadzona jest stosunkowo odległym mostem Gdańskim. TMP stanowić będzie północny fragment najbardziej zewnętrznej spośród planowanych trzech koncentrycznych obwodnic Warszawy - tzw. Obwodnicy Miejskiej. Niezwykłym osiągnięciem, tym samym godnym uwagi jest terminowe oddanie w użytkowanie trasy W-Z, dzięki której przeprawa na prawobrzeże środkami komunikacji miejskiej stała się beż wątpienia sprawniejsza ${ }^{31}$.

Podstawą systemu transportowego Warszawy jest transport publiczny, jego jakość decyduje zatem o sprawnym funkcjonowaniu całej metropolii. Najefektywniejszym środkiem transportu publicznego w Warszawie jest metro, które obsługuje jednak tylko ok.10\% przewozów miejskich, dlatego i w tym przypadku brak dostatecznej ilości taboru niekorzystnie wpływa na jakość usług i koszty eksploatacji. Z uwagi na to, jednym z najpilniejszych działań NPOP jest rozbudowa metra, druga linia ma powstać do roku 2020. Z racji tego, iż największe natężenie ruchu pasażerskiego przewidywane jest na odcinku od ronda Daszyńskiego po Dworzec PKP Warszawa Wileńska, odcinek ten budowany będzie jako pierwszy. Następnie powstaną odcinki obsługujące wielkie osiedla mieszkaniowe: Targówek i Bródno oraz Bemowo ${ }^{32}$.

Sytuacja podobnie przedstawia się w przypadku sieci tramwajowej, mimo iż Warszawa dysponuje dobrze rozwiniętą siecią tras tramwajowych, nie jest to jedyny argument za wyborem tego wariantu. Podróże bowiem są uciążliwe, tabor jest zużyty, przystanki są źle wyposażone. Z tego względu NPOP zakłada konieczność modernizacji tras tramwajowych, która polegać będzie głównie na poprawie stanu torowisk i zasilania, jak również wdrożenia Zintegrowanego Systemu Zarządzania Ruchem. Dzięki temu rozwiązaniu można będzie zapewnić tramwajom pierwszeństwo w sygnalizacji świetlnej. W ramach rozwoju systemu transportu publicznego modernizacji uległa trasa tramwajowa w Alejach Jerozolimskich. W latach kolejnych system będzie rozbudowywany na obszarze Śródmieścia, Pragi Północ, Południe oraz Targówka, Mokotowa, Ochoty, Woli i Żoliborza jak również na obszarze obejmującym trasy wylotowe z miasta. Wraz budową Mostu Północnego planowana jest budowa linii tramwajowej pomię-

\footnotetext{
30 Stowarzyszenie Integracji Stołecznej Komunikacji, Trasa Mostu Północnego [w:] http://siskom. waw.pl/tmp.htm, (7.02.2010); Życie Warszawy.pl, Warszawa, Komunikacja [w:] http://www. zw.com.pl/temat/344014.html, (7.02.2010).

31 Tamże.

32 Prezydent m.st. Warszawy, Informacja w zakresie ograniczenia emisji zanieczyszczeń powietrza ze źródeł komunikacyjnych. Pismo z dnia 14.08.2008r. skierowane do Marszałka Województwa Mazowieckiego, Pana A. Struzika, informacja znajduje się w Urzędzie Marszałkowskim; por. Zarząd Dróg Miejskich Warszawa, Zintegrowany System Zarządzania Ruchem, http://www. zdm.waw.pl/zintegrowany-system-zarzadzania-ruchem.html, (21.04.2009).
} 
dzy Białołęką a stacją metra Młociny (łącząca linię tramwajową Marymoncka/ Młociny z projektowaną linią Żerań-Most Północny-Winnica). Nacisk położony zostanie ponadto na przebudowę przystanków oraz polepszenie warunków komunikacji autobusowej. Usprawnieniu poddane zostaną węzly przesiadkowe, a na zatłoczonych odcinkach ulic tworzone będą wydzielone pasy dla autobusów mające na celu uprzywilejowanie ich w ruchu ulicznym. Komunikacja autobusowa zostanie ponadto objęta Zintegrowanym Systemem Zarządzania Ruchem, $\mathrm{w}$ efekcie pozwoli to na utrzymywanie ruchu zgodnie $\mathrm{z}$ rozkładem jazdy. $\mathrm{W}$ ścisłym centrum miasta rozszerzona zostanie strefa ulic ograniczona dla ruchu indywidualnego, uprzywilejowana natomiast na rzecz komunikacji autobusowej (Krakowskie Przedmieście) ${ }^{33}$. Zakłada się, że argumenty te powinny zwiększyć popularność sieci transportu publicznego, wpływając tym samym na poprawę jakości powietrza ${ }^{34}$.

W ramach realizacji NPOP nastąpi tzw. integracja systemu transportu publicznego. Do obsługi infrastruktury publicznej włączona zostanie kolej oraz węzły przesiadkowe, system parkingów „Parkuj i Jedź”, które celowo usytuowane zostaną przy stacjach metra (np. parking przy stacji metro Marymont). Do roku 2020 ZTM planuje budowę II etapu parkingów strategicznych, przygotowania obejmuja budowę ośmiu parkingów (m.in. na Alei Krakowskiej oraz przy stacjach „Kabaty”, „Ursynów”, „Wawer SKM”). Działanie to umożliwi bezpieczne pozostawienie samochodu i kontynuację podróży wybranym środkiem transportu publicznego. O ile pomysł jest wart uwagi, o tyle „polityka komunikacyjna” musiałby ulec radykalnym zmianom, aby zdołała zachęcić do wyboru takiego wariantu ponad prywatny środek komunikacji. Zarząd Transportu Miejskiego jako koordynator systemu parkingów podejmuje ponadto działania promujące transport zbiorowy m.in. „Dzień Bez Samochodu” czy też utworzenie miejskiej strefy zakazu palenia mającej na celu rozpowszechnianie idei zdrowego trybu życia ${ }^{35}$.

Na początku tej części artykułu zostały wyszczególnione trzy główne rodzaje emitorów mające wpływ na ponadnormatywne wskaźniki imisji. Z tego względu początkowo zajęto się emisją liniową - która przyczynia się w największym stopniu do skażenia powietrza na obszarze miasta. Z uwagi na fakt, iż najmniejszy wpływ na proces powstawania związków PM10 i NO2 ma emisja punktowa (generowana głównie przez elektrociepłownie Żerań i Siekierki, Energetyka Ursus Sp. z o.o.), program zawiera wąski zakres działań naprawczych, wśród których warto wymienić: zmianę technologii produkcji, w tym likwidacji źródeł o zna-

\footnotetext{
33 Miejskie Zakłady Autobusowe, Informacje Miejskich Zakładów Komunikacyjnych w Warszawie w sprawie niskoemisyjnych paliw i technologii, Pismo z dnia 21.07.2008, skierowane do Dyrektora Biura Ochrony Środowiska Urzędu Miasta Stołecznego Warszawy Pana D. Piechowskiego, informacja znajduje się w Urzędzie Marszałkowskim.

34 Tamże.

35 Tamże.
} 
czącej emisji PM10 i NO2; zmianę profilu produkcji wpływającej na ograniczenie emisji tychże substancji czy też stosowanie efektywnych technik odpylania gazów odlotowych.

Faktem godnym uwagi jest natomiast zbyt wąski zakres inwestycji ograniczających emisję powierzchniową. Rozkład stężeń PM10 i NO2 wskazuje sześć obszarów z ponadnormatywnymi poziomami imsji, trzy w dzielnicy Śródmieście, po jednym w dzielnicach Praga Północ, Włochy, Ursus. Na wysokie wartości stężeń tychże związków wpływa głównie wysoki udział indywidualnego ogrzewania węglowego, wykorzystywanie wyeksploatowanych instalacji, lokalizacja obiektów przemysłowych w centrum miasta jak i niedostateczny poziom wydatków budżetowych na ograniczenie emisji.

Z uwagi na to, iż jednym z głównych źródeł wartości ponadnormatywnych PM10 i NO infrastruktury ciepłowniczej oraz ograniczenie zużycia energii cieplnej ramach wspierania inicjatyw w zakresie termomodernizacji budynków. Ponadto promuje się zmianę paliwa na inne, o mniejszej zawartości popiołu czy też ograniczanie emisji z niskich rozproszonych źródeł technologicznych. Program przykłada zbyt małą wagę do wykorzystania szerokiego wachlarza energii pochodzącej ze źródeł odnawialnych, które to rozwiązanie jest obecnie jednym z najpowszechniej stosowanych działań w Europie. Planuje się tu jedynie wykorzystanie biogazu uzyskiwanego w oczyszczalniach ścieków czy w Zakładzie Unieszkodliwiania Stałych Odpadów Komunalnych ${ }^{36}$. Duże straty energii cieplnej spowodowane są złym stanem technicznym budynków, emisją powstającą w czasie prac remontowych, a także stosowaniem paliw o dużej zawartości popiołu w nieodpowiednio przystosowanych do tego paleniskach. Dobra sytuacja związana z ogrzewaniem zorganizowanym (gaz, elektryczność) przedstawia się jedynie na obszarze Śródmieścia oraz Mokotowie i Ursynowie.

Gruntownych modernizacji w zakresie zapewnienia bezpieczeństwa elektroenergetycznego wymaga również elektroenergetyka jako podsektor zapewniający funkcjonowanie miasta. Konieczne i zasadne staje się monitorowanie awaryjności sieci elektroenergetycznych, tworzenie korzystnych warunków do inwestowania w infrastrukturę elektroenergetyczną miasta oraz wspieranie budowy lokalnych źródeł wytwarzania energii elektrycznej niezbędnych w celu zwiększenia bezpieczeństwa, ponadto ogromną wagę należy przyłożyć do propagowania nowych technologii i standardów organizacji ${ }^{37}$.

\footnotetext{
36 Załącznik nr 1 do uchwały Nr LXIX/2063/2006 Rady m.st. Warszawy z dnia 27 lutego 2006 roku w sprawie przyjęcia Polityki energetycznej m.st. Warszawy do 2020 r.[w:] http://um.warszawa.pl/v_syrenka/bi/polityka_energetyczna_2020.pdf, (22.04.2009); Kluczowe inwestycje dla systemów energetycznych (dane przedsiębiorstw energetycznych) http://bip.warszawa.pl/NR/ exeres/76CF3769-AA54-4966-BC6F-C0556071FEC5,frameless.htm, (21.04.2009).

37 Tamże, Podsektor elektroenergetyczny.
} 
W Programie powinien zostać umieszczony nakaz realizacji pilotażowego programu budownictwa mieszkaniowego $\mathrm{w}$ systemie ogrzewania pasywnego oraz zasilania budynków ze źródeł odnawialnych. Powyższe koncepcje w połączeniu z odpowiednim wykorzystaniem dwóch elektrowni systemowych (obecnych na terenie miasta) wspomaganych elektrociepłowniami, oraz dostęp do krajowej sieci gazociągów, bez wątpienia wpłynęłyby na poprawę stanu powietrza na obszarze stolicy. W obrębie sektora energetycznego znajduje się również wiele podsektorów, podlegających konieczności modernizacji zgodnie z normami obowiązującymi na terenie Wspólnoty Europejskiej w celu przywrócenia odpowiedniej jakości stanu powietrza.

Wyżej wymienione działania stanowią potencjalne kierunki zmierzające do poprawy jakości powietrza. Do działań zawartych w NPOP w zakresie likwidacji emisji powierzchniowej do roku 2015 planuje się jedynie podłączenie lokalnych systemów ogrzewania budynków komunalnych i użyteczności publicznej w zabudowie ogrzewanej indywidualnie (obiekty w dzielnicy Włochy i Ursus) do miejskiej sieci ciepłowniczej. Program jako instrument prawny powinien obejmować swą reglamentacją wszystkie wyżej wymienione kierunki działań, bowiem jedynie holistyczne podejście do problemu jest w stanie poprawić obecną sytuację.

W celu przeciwdziałania zanieczyszczeniom powietrza niezbędna staje się ochrona i rewaloryzacja środowiska przyrodniczego prowadząca jednocześnie do zapewnienia trwałego i zrównoważonego rozwoju. W tym celu konieczne jest podjęcie odpowiednich kroków ukierunkowanych na ograniczenie emisji $\mathrm{w}$ ramach prawidłowego podejścia $\mathrm{w}$ zakresie planowania przestrzennego. Przedsięwzięciem niezwykle istotnym w zakresie przeciwdziałania kumulacji zanieczyszczeń jest odtworzenie i ochrona systemu przewietrzania miasta, tzw. klinów napowietrzających. Dyspersja zanieczyszczeń na terenie Warszawy „wspomagana" jest bowiem zachodnimi wiatrami z Kampinoskiego Parku Narodowego przynosząc tym samym czyste powietrze. Stolica posiada obszary pełniące rolę korytarzy wymiany powietrza, na terenach tych zatem powinien istnieć bezwzględny zakaz lokalizacji urządzeń i instalacji czy też zabudowy ograniczającej swobodny przepływ mas powietrza. Likwidacja klinów zahamuje cyrkulację powietrza pomiędzy miastem i przedmieściami, podwyższając koncentracje szkodliwych gazów i pyłów. Obecna polityka przestrzenna dopuszcza na tym obszarze (wzdłuż Alei Jerozolimskich, Żwirki i Wigury czy północnej obwodnicy kolejowej) wysoką zabudowę czy też lokalizację dróg, zwłaszcza węzłów drogowych, tworząc tym samym dodatkowe źródła emisji ${ }^{38}$.

NPOP przywołać powinien zapis zawarty w „Polityce Transportowej dla miasta stołecznego Warszawy do 2015 roku”, w postaci obowiązku stymulowa-

38 Tamże. 
nia koncentracji budownictwa mieszkaniowego o dużej gęstości, obiektów użyteczności publicznej i centrów handlowo-usługowych w obszarach dobrze obsłużonych transportem zbiorowym, w tym zwłaszcza w bezpośredniej bliskości przystanków transportu szynowego. Zasadniczym błędem, który uwzględniono w ramach konsultacji do NPOP jest zabudowa terenów tzw. Zielonej Białołęki (Augustówek, Grodzisk, Brzeziny, Kobiałka) obsługiwanej zaledwie 4 liniami autobusowymi o niskiej częstotliwości kursowania. Kolejny mankament to budowa stacji 110/15 kV RPZ Powiśle bez wcześniejszej realizacji linii tramwajowej, czy inwestycja centrum handlowego Marki przy obsłudze tego terenu pierwotnie tylko jedną linią autobusową ą $^{39}$

Zmiany w sektorze komunikacji i energetyki wpływają bez wątpienia najkorzystniej na obniżenie poziomów zanieczyszczeń powietrza atmosferycznego, warto jednak zwrócić uwagę na promocję działań edukacyjnych w zakresie ochrony środowiska przyrodniczego. Odpowiednia promocja bądź reklama może stanowić niezwykle silny bodziec skłaniający do konsumpcji konkretnego dobra, bądź przyjęcia postawy proekologicznej. Dlatego tak istotne jest praktykowanie ogólnoświatowych kampanii, wśród których popularnością cieszy się Dzień bez Samochodu, Dzień Ochrony Klimatu, Tydzień Zrównoważonego Transportu.

$\mathrm{W}$ tym miejscu warto przytoczyć pewną myśl A. Papuzińskiego, definiującą termin sumienia ekologicznego, które jest według Autora „zdolnością reagowania na sposób własnego i cudzego oddziaływania na stan natury" ${ }^{\prime 2}$. Wynika z tego, jak ważne miejsce zajmuje nasze pojęcie świadomości ekologicznej wykształcone w procesie wychowania w duchu poszanowania środowiska.

\section{Zakończenie}

Celem Naprawczego Programu Ochrony Powietrza dla strefy „aglomeracja warszawska" jest dążenie do przywrócenia dopuszczalnych wartości stężeń PM10 i $\mathrm{NO}_{2}$ zgodnych z przyjętymi normami wynikającymi z faktu członkowstwa Polski w Unii Europejskiej. Jest to sytuacja wymagająca podjęcia wielu działań. Warszawa, jako stolica Rzeczypospolitej Polskiej, miasto o bogatych tradycjach, powinna dążyć do osiągnięcie jak najwyższego poziomu życia mieszkańców zgodnego z koncepcją zrównoważonego rozwoju w duchu cywilizacji europejskiej.

Naprawczy Program Ochrony Powietrza w swoim założeniu ma kształtować, wspierać jak również przekonywać społeczeństwo do odpowiednich zachowań względem zasobów środowiska przyrodniczego. Jest on ponadto nie tylko instru-

\footnotetext{
39 Tamże.

40 Zob. A. Papuzıński, Życie, nauka, ekologia. Prolegomena do kulturalistycznej filozofii ekologii, Wyd. WSP, Bydgoszcz 1998, s. 250, za: M. Haliniak, Filozofia polityki ekologicznej...dz. cyt.,. Podstawy filozoficzne, s. 75.
} 
mentem służącym poprawie stanu jakości atmosfery, a tym samym dobrostanu zdrowia ludzkiego, ale narzędziem wspomagającym i przyspieszającym realizacje inwestycji w zakresie modernizacji infrastruktury komunikacyjnej, energetycznej czy też poprawy warunków estetycznych miasta poprzez odpowiednie zagospodarowanie przestrzenne. Działania te propagują wzorce wpływające na dalsze kształtowanie procesów zachodzących w wymiarze zarówno regionalnym jak i krajowym, stanowiąc tym samym pewien wkład w działalności międzynarodowej na rzecz przeciwdziałania zmianom klimatu

\section{Realization of Air Protection Repair Program (NPOP)}

\section{SUMMARY}

The aim of the present article is to approach the problems connected with air pollution and also with different types of scientific, legal and administrative activities in the field of atmosphere protection. The research has been carried out on the territory of Warsaw agglomeration. In connection with this fact all means of administration are referred to the present political and economical conditions of Warsaw agglomeration.

Air Protection Repair Program (NPOP), making up the content of the present work, introduces the resolutions in the field of management of the quality of the air based on the norms used on the territory of the European Union and shows governmental activities directed to attainment of common standard of the development of the capital at the arena of other European agglomerations.

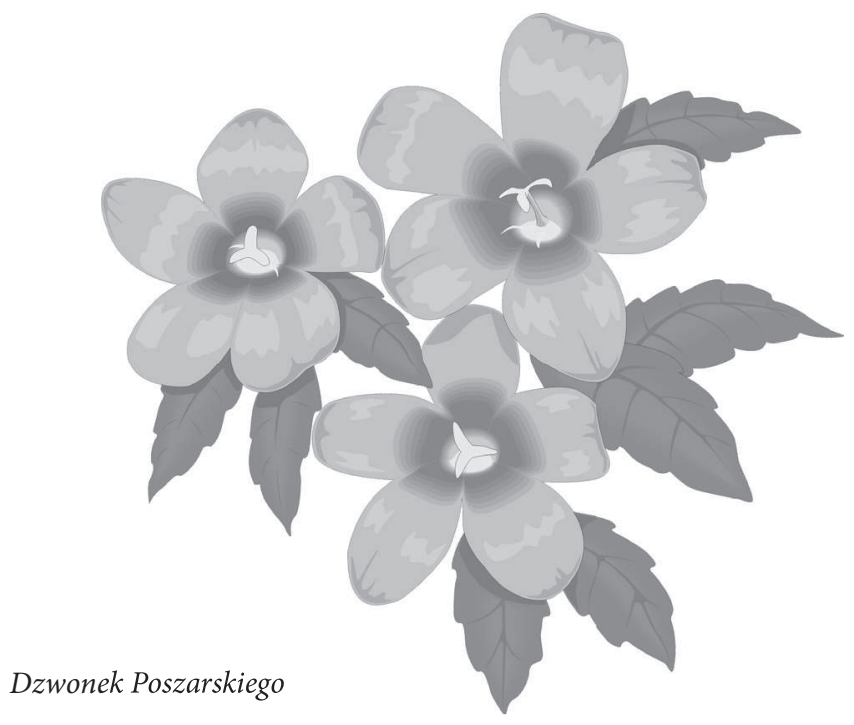

